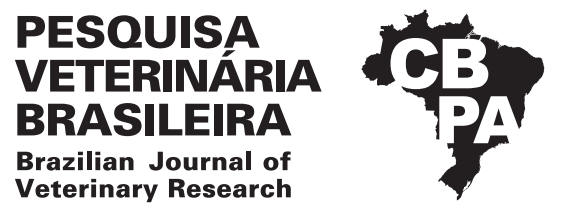

Pesq. Vet. Bras. 39(1):12-19, janeiro 2019 DOI: 10.1590/1678-5150-PVB-5668

Original Article

ISSN 0100-736X (Print)

ISSN 1678-5150 (Online)

\title{
Current trends in bovine abortion in Argentina ${ }^{1}$
}

\author{
Eleonora L. Morrell ${ }^{*}$ (D), Carlos M. Campero², Germán J. Cantón², Anselmo C. Odeón², \\ Dadín P. Moore ${ }^{3}$, Ernesto Odriozola ${ }^{2}$, Fernando Paolicchi ${ }^{2}$ and María A. Fiorentino ${ }^{2}$
}

\begin{abstract}
Morrell E.L., Campero C.M., Cantón G.J., Odeón A.C., Moore D.P., Odriozola E., Paolicchi F. \& Fiorentino M.A. 2019. Current trends in bovine abortion in Argentina. Pesquisa Veterinária Brasileira 39(1)12-19. Animal Health Group, Instituto Nacional de Tecnología Agropecuaria (INTA), Ruta 226 Km73, 5 (7620), Balcarce, Argentina. E-mail: morrell.eleonora@inta.gob.ar

Bovine abortion is an important cause of significant economic losses in beef and dairy herds. This syndrome is usually difficult to diagnose. The aim of this study was to characterize bovine abortion causes in Argentina by standard diagnosis procedures (histology, bacterial and viral isolation) and other diagnostic tests like direct fluorescent antibody test (DFAT), fetal serology, immunohistochemistry (IHC), and PCR, showing their specific advantages and limitations. Necropsies were performed in 150 aborted bovine fetuses submitted to the diagnostic laboratories of Instituto Nacional de Tecnología Agropecuaria (INTA) Balcarce, Argentina. Etiological diagnosis was confirmed in 78 fetuses (52\% of the cases). Most causes of abortion were of infectious origin, being Neospora caninum (14.67\%), Campylobacter fetus sp. (9.33\%), Leptospira spp. (7.33\%) and Brucella abortus (6.65\%) the main microorganisms identified. Bovine viral diarrhea virus (BVDV) and bovine herpes virus (BHV) were diagnosed in $2(1.33 \%)$ and $3(2 \%)$ cases, respectively. This study showed a better characterization of bovine abortion compared with previous researches done on this topic.
\end{abstract}

INDEX TERMS: Current trends, bovine, abortion, fetuses, diagnosis, PCR, Argentina, surgery.

\begin{abstract}
RESUMO.- [Tendências atuais do aborto bovino na Argentina.] 0 aborto bovino é uma causa importante de perdas econômicas significativas em rebanhos bovinos e leiteiros. Esta síndrome é geralmente difícil de diagnosticar. 0 objetivo deste estudo foi caracterizar o aborto bovino na Argentina por procedimentos diagnósticos de rotina (histologia, isolamento viral e bacteriana) e outros testes diagnósticos como ensaio directo de anticorpos fluorescentes (DFAT), sorologia fetal, imuno-histoquica (IHC), e PCR; mostrando suas vantagens e limitações específicas. As necropsias foram realizadas em 150 fetos bovinos abortados submetidos aos laboratórios de diagnóstico do Instituto Nacional de Tecnologia Agropecuária (INTA) de Balcarce, na Argentina. 0 diagnóstico etiológico foi confirmado em 78 fetos ( $52 \%$ dos casos). A maioria das causas de aborto foram de origem infecciosa, sendo

\footnotetext{
${ }^{1}$ Received on September 3, 2018.

Accepted for publication on September 19, 2018.

${ }^{2}$ Animal Health Group, Instituto Nacional de Tecnología Agropecuaria (INTA), Ruta $226 \mathrm{Km} \mathrm{73,5} \mathrm{(7620),} \mathrm{Balcarce,} \mathrm{Argentina.} \mathrm{*Corresponding}$ author: morrell.eleonora@inta.gob.ar

${ }^{3}$ Consejo Nacional de Investigaciones Científicas y Técnicas (Conicet), Argentina.
}

Neospora caninum (14,67\%), Campylobacter fetus sp. (9,33\%), Leptospira spp. (7,33\%) e Brucella abortus (6,65\%) os principais microrganismos identificados. 0 vírus da diarréia viral bovina (BVDV) e o herpesvírus bovino (BHV) foram diagnosticados em $2(1,33 \%)$ e $3(2 \%)$ casos, respectivamente. Este estudo mostrou uma melhor caracterização do aborto bovino em comparação com pesquisas anteriores feita sobre este tema.

TERMOS DE INDEXAÇÃO: Tendências atuais, aborto, bovinos, fetos, diagnóstico, PCR, Argentina, cirurgia.

\section{INTRODUCTION}

Bovine abortion is one of the most important problems of livestock production and health, causing severe economic loss. The worldwide diagnosis of bovine abortion is difficult and costly (Anderson et al. 1990, Kirkbride 1990, Campero et al. 2003, Anderson 2007, Holler 2012). Several studies reported that a definitive etiologic diagnosis of bovine abortion was achieved in 23.3 to $45.5 \%$ of the cases (Campero et al. 2003, Anderson 2007, Campero et al. 2017).

Amongst the causes of bovine abortion, infectious causes are the most prevalent (Hubbert et al. 1973, Corbellini et al. 2006, 
Anderson 2007, Bon Durant 2007). Factors such as production type, climate, management practices and vaccination programs are able to determine differences in the frequency of various infectious abortigenic agents identified (Anderson 2007). Non-infectious bovine abortions had been described, but these losses are difficult to establish (Kirkbride 1990).

Traditional diagnostic tools include macroscopic examination, histology, and bacterial and viral isolation (Campero et al. 2003, Anderson 2007). Pathogen isolation is considered the "gold standard" test for detection of infectious agents; however these techniques are laborious, time-consuming and in some cases had low sensitivity (Smith et al. 1994, Seleem et al. 2010). The application of immunohistochemistry (IHC) and PCR had improved the identification of infectious agents in bovine fetuses (Richtzenhain et al. 2002, Van Maanen et al. 2004, Cortez et al. 2006, Silva et al. 2009, Tramuta et al. 2011). This study assesses the most important, bacterial, viral, fungal and protozoal causes of bovine abortion in Argentina, focusing on the methods used to reach an accurate diagnosis.

\section{MATERIALS AND METHODS}

Diagnostic criteria. The causes of bovine abortion were classified as determined (including infectious and non- infectious origin) and undetermined (with or without histological lesions), respectively.

Specimens, origin and macroscopic examination procedures. Samples were collected from 150 bovine aborted fetuses that had undergone spontaneous abortion from 2004 to 2006. Fetuses were submitted by veterinary practitioners or private veterinary diagnostic laboratories to the Specialized Veterinary Diagnostic Service at INTA Balcarce, Argentina. Only two fetuses were sent with their placenta. Full necropsies were performed in all fetuses, including the examination of both placentas. Herd origin and other epidemiological information were collected in most of the cases. The differentiation between abortion and perinatal mortality was evaluated by the hydrostatic pulmonary docimasy test (presence or absence of aerated lungs) and by the presence of hemorrhage and/or thrombosis surrounding the umbilical vessels. Fetal deaths due to dystocia were diagnosed based on the presence of head swelling, subcutaneous edema, and/or fractures of the ribs and limbs.

Fetal age was estimated based on the crown-rump length (Hubbert et al. 1973, Kirkbride 1986). The state of post-mortem decomposition was estimated using a subjective score from 1 (slight) to 3 (severe). A score of 2 indicated moderate decomposition.

Histology and special staining. Samples of cerebrum, lung, heart, liver, spleen, kidneys, adrenal glands, thymus, lymph-nodes, skeletal muscle, abomasum, small intestine and colon from all fetuses and samples from two placentas, were fixed in 10\% neutral buffered formalin, embedded in paraffin, processed routinely and stained with hematoxylin and eosin (HE) (Campero et al. 2003). In addition, selected sections were stained with Gram, Grocott and Warthin-Starry (Campero et al. 2003).

Microbiological cultures. Samples of fetal lung and abomasal content were cultured for aerobic and microaerophilic bacteria (Campero et al. 2003). Campylobacter fetus was isolated by culture of abomasal content on blood agar and incubating the plates under microaerophilic conditions (Campero et al. 2003). Further additional phenotypic test were employed to identify the species and subspecies. The criteria to confirm opportunistic bacteria as a cause of abortion were: 1) isolation of the bacteria in pure culture from abomasal content and/or lung; 2) presence of pathological lesions consistent with bacterial infection in the fetus; 3 ) exclusion of other common abortigenic agents (Kirkbride 1993, Yaeger \& Holler 2007).

For virus isolation, samples of fetal spleen were inoculated into Madin-Darb Bovine Kidney (MDBK) cells. After 4 blind passages, cultures were tested for BVDV and BHV antigens by IFAT procedure with two commercially available polyclonal antibodies, respectively (American Bio-Research, Sevierville/TN, USA).

The identification of Tritrichomonas foetus was performed inoculating fetal abomasal content into the liver broth medium. The samples were incubated at $37^{\circ} \mathrm{C}$ and examined under optic microscope at 20x during 7 days (Campero et al. 1986).

Fetal abomasal content and lung was cultured on Sabouraud's dextrose agar from fetuses that had macroscopic pathological findings compatible with mycotic infections.

Direct fluorescent antibody test (DFAT). Smears of liver, lung, kidney and aqueous humor were performed routinely for Leptospira spp. identification by DFAT. Fluorescein labeled rabbit polyclonal antibodies (Lepto Multivalent FA Conjugate, National Veterinary Services Laboratories, Ames/IA, USA) at a 1:20 dilution was used. Samples were examined under a fluorescence microscope at $40 \mathrm{x}$. Smear from a culture of $L$. interrogans was prepared as a positive control.

Similarly, C. fetus DFAT was performed routinely from fetal abomasal content as previously described (Campero et al. 2003). A C. fetus venerealis conjugate (Conjugado-campy, Laboratorio Biologico de Tandil S.R.L, Tandil, Argentina) at a 1:20 dilution was employed. Samples were examined under a fluorescence microscope (Nikon Fluophot). Smears from cultures of $C$. fetus venerealis and C. sputorum bubulus were employed as positive and negative controls, respectively.

Fetal serology (FS). Fetal fluids from thoracic and abdominal cavities were tested for Neospora caninum antibodies as previously described (Dubey et al. 1988). Titers $\geq 1: 25$ were considered as evidence of $N$. caninum infection (Wouda et al. 1997).

The presence of antibodies against BVDV and BHV were performed from samples of thoracic and abdominal fetal fluids using the microtitre technique, as previously described (Odeón et al. 2001). Serial dilutions of the samples were incubated with a viral inoculum containing 100 TCID50/50 $\mu$ l for 1 hour at $37^{\circ} \mathrm{C}$. A suspension of MDBK cells was added and incubation continued at $37^{\circ} \mathrm{C}$. Antibody titer was determined as the highest dilution that showed complete inhibition of the cytopathic effect after 72 hours of incubation. Titers $\geq 1$ :8 were considered indicative of fetal infection (Odeón et al. 2001).

Immunohistochemistry (IHC). Selected samples of brain with microscopic lesions (focal or multifocal lymphohistiocytic encephalitis with gliosis and/or necrosis) compatible to N. caninum infection were processed. Polyclonal antibodies against this protozoon at a 1:300 dilution (kindly provided by Dr. M. Anderson, UCDavis, USA) were employed. An Avidin Biotin commercial kit (ABC Elite ABC Peroxidase Complex Vector PK6101, Vector, Burlingame, USA) was employed according to the instruction of the manufacturer. AEC substrate chromogen K3464 (Dako, Carpinteria, CA, USA), was used as previously described (Campero et al. 2003).

PCR. Fetal tissues were taken during the necropsy and stored at $-80^{\circ} \mathrm{C}$ until processing. Selected tissues and PCR protocols (Table 1) were collected for detection of N. caninum (Baszler et al. 1999), Leptospira spp. (Mérien et al. 1992), Brucella abortus (Morrell 2010), C. fetus venerealis (Schulze et al. 2006), T. fetus (Bon Durant et al. 2003), BHV (Takiuchi et al. 2005) and BVDV (Ridpath et al. 1994). The PCR was applied in 38 fetuses that only had microscopic lesions suggestive of infectious etiology. In addition, the PCR was employed to confirm 
the cause of abortion in fetuses positive to Leptospira spp. by DFAT (11 fetuses); and in fetuses with serology to N. caninum (11), BHV (14) and BVDV (15). DNA was extracted using a commercial kit (DNeasy, Blood and Tissue kit, QIAGEN, Frankfurt, Germany) and PCR conditions was applied accordingly (Table 1). PCR products were revealed by electrophoresis on a $2 \%$ agarose gel and stained with ethidium bromide. Positive (DNA from infectious agent) and negative (bi-distilled water) controls were included appropriately.

Statistics. A generalized linear model with Poisson distribution (Proc. Gen. Mod) (SAS 2002) was applied in order to establish association between etiologic diagnosis, herd origin and trimester of gestation. $\mathrm{Chi}^{2}$ test (Proc Freq) (SAS 2002) was used to identify significant differences between herd type (beef versus dairy), determined and undetermined causes of abortion, and the presence or absence of lesions. Differences were considered significant for $P<0.05$.

\section{RESULTS}

The etiology of bovine abortion was identified in 78 of 150 (52\%) fetuses. Infectious causes were determined in 72 of 150 bovine fetuses; being 32 of 72 identified by standard diagnosis procedures, and 40 of 72 by other diagnostic test (Table 2).

Non-infectious causes of bovine abortion were determined in four fetuses that had congenital malformations, and in two fetuses with iatrogenic origin suspicion (Table 2). Congenital malformations consisted of arthrogryposis (Fig.1), hydrocephalus, cheiloschisis and lumbar spina bifida. The first iatrogenic abortion was related with Bacillus anthracis (Stern strain) vaccination and subsequent abortion during late gestation. In this case, B. anthracis was isolated from abomasal content and fetal lung and microscopic lesions was observed in the fetus. The second iatrogenic abortion was attributed to generalized hypersensitivity reaction, after the administration of a parenteral multivitamin complex injected to the dam.

In a total of 72 abortions the cause was undetermined (Table 2). In all these cases, infectious agents were not detected but 38 of 72 fetuses had microscopic lesions suggestive of infectious etiology (Table 2).
Specimens, origin and macroscopic examination procedures. A total of 150 bovine fetuses from 77 herds from Buenos Aires province were analyzed; 104 (69.2\%) were submitted from beef (Aberdeen Angus, Hereford and their crosses) and 35 (23.4\%) from dairy herds (Holstein and Jersey). Information regarding type of herd was not received for 11 fetuses (7.4\%). The number of fetuses submitted for diagnosis from beef herds was significantly higher $(p<0.05)$ than from dairy herds. Seventy six (50.6\%) and 58 fetuses $(38.6 \%)$ were male and female $(p<0.05)$, respectively, and in $16(10.6 \%)$ cases the gender was not recorded. The gestational ages of 80 fetuses (53.3\%) corresponded to the third trimester of the pregnancy. A total of 57 fetuses (38\%) aborted in the second trimester of the pregnancy, and five fetuses (3.33\%) in the first trimester. In eight fetuses (5.33\%) the gestational age could not be recorded.

A high degree of autolysis (score 2 to 3) was observed in $61 \%$ of the fetuses, and the remaining fetuses had slight autolysis (score 1) $(p<0.05)$.

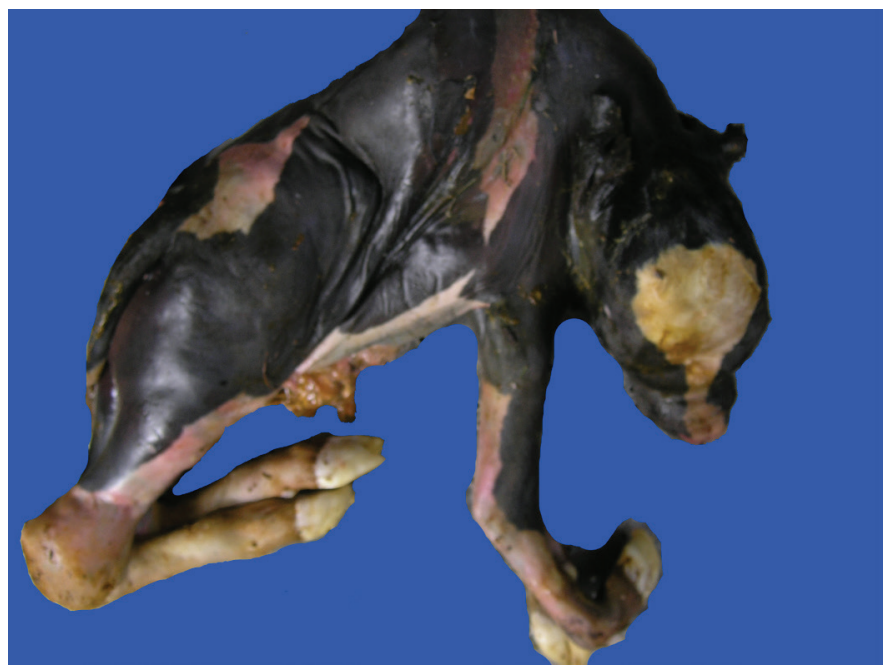

Fig.1. Aborted bovine fetus with arthrogryposis.

Table 1. PCR conditions of Brucella abortus, Campylobacter fetus venerealis, Leptospira spp., BVDV, BHV, Neospora caninum and Tritrichomonas foetus for diagnosis of bovine abortion

\begin{tabular}{|c|c|c|c|c|c|c|}
\hline Infectious agent & Analyzed tissues & Primers & $\begin{array}{c}\text { Annealing } \\
\left({ }^{\circ} \mathrm{C}\right)\end{array}$ & Cycles & $\begin{array}{l}\text { Product } \\
\text { (bp) }\end{array}$ & References \\
\hline B. abortus & Lung, $\mathrm{AC}^{\mathrm{a}}$ & $\begin{array}{l}\text { tgccgatcacttaagggccttcat } \\
\text { gacgaacggaatttttccaatcc }\end{array}$ & 58 & 40 & 498 & Morrell 2010 \\
\hline C. fetus venerealis & Lung, AC & $\begin{array}{l}\text { ggtagccgcagctgctaagat } \\
\text { tagctacaataacgacaact }\end{array}$ & 55 & 35 & 142 & Schulze et al. 2006 \\
\hline Leptospira spp. & $\begin{array}{l}\text { Liver, lung, kidney, aqueous } \\
\text { humor }\end{array}$ & $\begin{array}{l}\text { ggcggcgcgtcttaaacatg } \\
\text { ttagaacgaagttaccccctt }\end{array}$ & 63 & 29 & 331 & Mérien et al. 1992 \\
\hline BVDV & Spleen & $\begin{array}{l}\text { ccatgtgccatgtacag } \\
\text { catgcccatagtaggac }\end{array}$ & 48 & 25 & 283 & Ridpath et al. 1994 \\
\hline BHV & Spleen & $\begin{array}{l}\text { aacatgcaagggccgacattgg } \\
\text { gaccgtgccgtcgatgtacagc }\end{array}$ & 55 & 30 & 552 & Takiuchi et al. 2005 \\
\hline N. caninum & $\mathrm{CNS}^{\mathrm{b}}$ & $\begin{array}{l}\text { cagtcaacctacgtcttct } \\
\text { gggtgaaccgagggagttg }\end{array}$ & 56 & 35 & 227 & Baszler et al. 1999 \\
\hline T. foetus & Lung, AC & $\begin{array}{l}\text { cgggtcttcctatatgagacagaacc } \\
\text { cctgccottggatcagtttcgttaa }\end{array}$ & 67 & 40 & 347 & Bon Durant et al. 2003 \\
\hline
\end{tabular}

$\overline{{ }^{\mathrm{a}} \mathrm{AC}=\text { Abomasal }}$ content, ${ }^{\mathrm{b}} \mathrm{CNS}=$ central nervous system 
Table 2. Diagnosis of bovine abortions in 150 fetuses

\begin{tabular}{|c|c|c|c|c|c|c|c|}
\hline \multirow{2}{*}{ Diagnostic } & \multirow{2}{*}{$\mathrm{SDP}^{\mathrm{a}}$} & \multicolumn{5}{|c|}{ Other diagnostic test* } & \multirow{2}{*}{ Percentage of total } \\
\hline & & $\mathrm{PCR}^{\mathrm{b}}$ & $\mathrm{FS}^{\mathrm{c}}+\mathrm{PCR}$ & $\mathrm{DFAT}^{\mathrm{d}}+\mathrm{PCR}$ & $\mathrm{IHC}^{\mathrm{e}}$ & Total & \\
\hline Determined causes & & & & & & 78 & 52.0 \\
\hline \multicolumn{8}{|l|}{ Infectious } \\
\hline Ccampylobacter fetus sp. & 14 & & & & & & 9.33 \\
\hline Leptospira spp. & & & & 11 & & & 7.33 \\
\hline Trueperella pyogenes & 2 & & & & & & 1.33 \\
\hline Aeromonas hydrophila & 1 & & & & & & 0.68 \\
\hline Listeria monocytogenes & 1 & & & & & & 0.68 \\
\hline b) Protozoal & & & & & & 24 & 16.0 \\
\hline Neospora caninum & & 5 & 6 & & 11 & & 14.67 \\
\hline$B V D V$ & 2 & & 0 & & & & 1.33 \\
\hline$B H V$ & & & 3 & & & & 2.0 \\
\hline Non infectious & & & & & & 6 & 4.0 \\
\hline Malformations & 4 & & & & & & 2.67 \\
\hline Iatrogenic & 2 & & & & & & 1.33 \\
\hline Undetermined causes & & & & & & 72 & 48.0 \\
\hline With histological lesion & 38 & & & & & & 25.33 \\
\hline Without histological lesion & 34 & & & & & & 22.67 \\
\hline
\end{tabular}

* Include the histology in all cases; ${ }^{\text {a SDP } ~=~ s t a n d a r d ~ d i a g n o s t i c ~ p r o c e d u r e s ~(i n c l u d e ~ h i s t o l o g y, ~ b a c t e r i a l, ~ a n d ~ v i r a l ~ i s o l a t i o n), ~}{ }^{\text {b }}$ PCR $=$ polymerase chain reaction, ${ }^{\mathrm{c}} \mathrm{FS}=$ fetal serology, ${ }^{\mathrm{d}} \mathrm{DFAT}=$ direct fluorescence antigen test,${ }^{\mathrm{e}} \mathrm{IHC}=$ Immunohistochemistry.

Macroscopic lesions like jaundice caused by Leptospira pomona, fibrinous pericarditis and/or pleuritis caused by B. abortus, circumscribed plaques on the skin, and necrotic placentitis caused by Aspergillus fumigatus were observed in some fetuses.

Histology and special staining. The most common microscopic lesions associated with the infectious agent identified were: neutrophilic bronchopneumonia, lymphohistiocytic meningitis with B. abortus and Campylobacter fetus venerealis, lymphohistiocytic bronchopneumonia and occasional presence of giant cells with Tritrichomonas foetus (Fig.2), neutrophilic bronchopneumonia with Trueperella pyogenes, lymphohistiocytic folliculitis, lymphohistiocitic bronchopneumonia, necrotic placentitis with $A$. fumigatus, lymphohistiocytic interstitial nephritis, lymphohistiocytic meningitis, lymphohistiocytic periportal hepatitis with L. interrogans, neutrophilic multifocal hepatitis with Listeria monocytogenes, focal lymphohistiocytic encephalitis with necrosis and/or gliosis, lymphohistiocytic myocarditis and/or pericarditis, lymphohistiocitic interstitial pneumonia, and portal lymphohistiocitic hepatitis with foci of necrosis with $N$. caninum, lymphohistiocytic interstitial myocarditis, lymphohistiocytic vasculitis with BVDV and multifocal hepatic necrosis with BHV.

The presence of fungal-like structures (hiphas) from skin sections were identified by Grocott stain. Leptospira-like organisms were stained by Warthin-Starry from sections of kidneys and/or liver. Intra-alveolar cluster of T. pyogenes was stained by Gram.

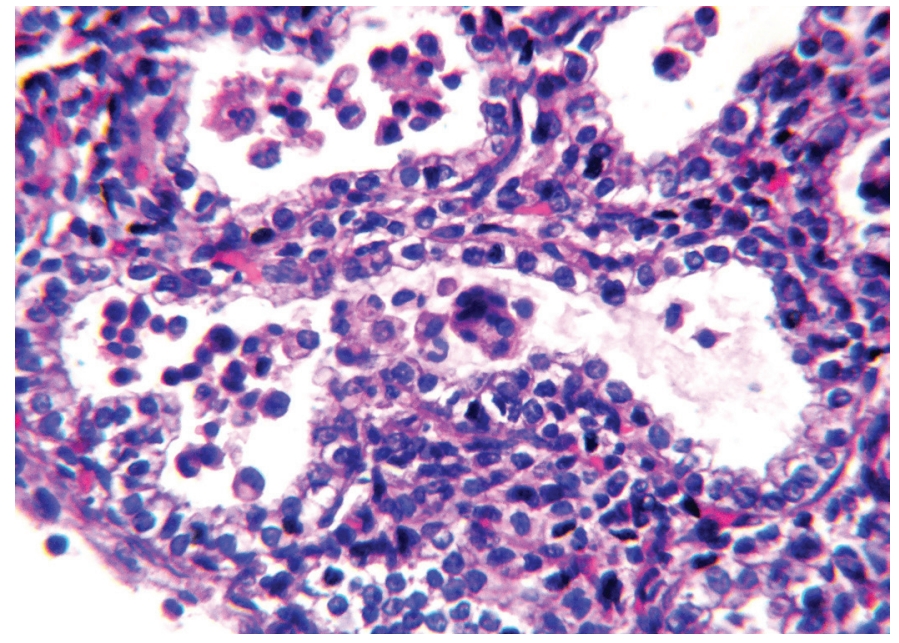

Fig.2. Lymphohistiocytic bronchopneumonia with occasional presence of giant cell from a bovine fetus positive to Tritrichomonas foetus. HE, obj.40x.

Microbiological cultures. A total of 129 samples of abomasal content or lung were available for bacteria, and T. foetus culture. Bacterial infectious agents were identified in 29 of 129 of those samples: C. fetus venerealis (14), B. abortus (6), T. pyogenes (2), Aeromonas hydrophila (1), 
L. monocytogenes (1), Streptococcus $\alpha$ hemolytic (3) (Table 2). T. foetus was identified in two opportunities from abomasal contents. For BVDV and BHV isolation 129 spleens were available. BVDV was isolated in 2 of 129 samples, while BHV was not isolated (Table 2). A. fumigatus was isolated from abomasal content and lung in one fetus.

DFAT. Fluorescent Leptospira-like structures were observed in 11 of 150 (Table 2) smears of kidneys (3), lung (1), liver and kidney (3), aqueous humor (3) and aqueous humor and kidney (1). Campylobacter-like structures were observed by DFAT in 14 of 150 samples of abomasal content processed (data not show).

Fetal serology. Fetal fluids from 110 fetuses were examined. Antibodies against $N$. caninum, BHV and BVDV were detected in 11,14 and 15 fetuses respectively.

IHC. Positive immunostaining to $N$. caninum structures (tachyzoites and tissue cysts) were observed in the 11 fetuses with microscopic lesions compatible with this parasite (Fig.3). Only two of those fetuses had antibodies to N. caninum.

PCR. This technique was positive to $N$. caninum and B. abortus in 5 of 38 CNS and 4 of 38 lungs (Fig.4), respectively. These 38 fetuses had microscopic lesions suggestive of infectious etiology (see discussion).

The inclusion of PCR confirmed the etiologic diagnosis in 11 of 11 fetuses positive to Leptospira spp. by DFAT. In addition, PCR confirmed the cause of abortion in 6 of 11 and 3 of 14 fetuses with serology to $N$. caninum and BHV, respectively; but PCR was negative in 15 fetuses that had antibodies to BVDV (Table 2). In each one of these cases, the fetuses had inflammatory lesions compatible to the agent involved.

\section{DISCUSSION}

The etiology of bovine abortion is identified in less than half of the fetuses submitted (Campero et al. 2003, Campero 2006, Anderson 2007), being the degree of decomposition, fetal contamination, and absence of the placenta the main limiting factors for this low sensitivity (Kirkbride 1986, Holler 2012). In addition, laboratory procedures available, as well as sampling, are critical factors for the successful of the diagnosis (Thurmond et al. 1994, Holler 2012).

In the current work, the etiology of bovine abortion was identified in $52 \%$ of the fetuses submitted. This result was higher than previous works (Kirkbride, 1990, 1993, Campero et al. 2003) in which PCR was not included.

Most of the fetuses analyzed came from beef herds and were recovered during the last third of gestation. Estimation of fetal gestational age is a useful parameter when abortions are of infectious origin. Diseases like Tritrichomonas foetus, Leptospira spp. serovar Hardjo and BVDV can cause early fetal losses. Most of abortions due to Neospora caninum occur between five to seven months of gestation. Campylobacter fetus and HVB are frequently identified in fetuses of five to nine month of gestation, while Brucella abortus, and L. pomona cause abortions during the last third of gestation.

Coincidently to previous reports (Anderson et al. 1990 1991, Kirkbride 1993, Campero et al. 2003, Campero 2006, Jamaludin et al. 1996, Morrell 2010) in this study, infectious etiology was the main cause of abortion.

Brucelosis is a zoonotic and chronic disease that causes important losses due to abortion, stillbirth and infertility in ruminants (Campero et al. 2017). Despite the inclusion of

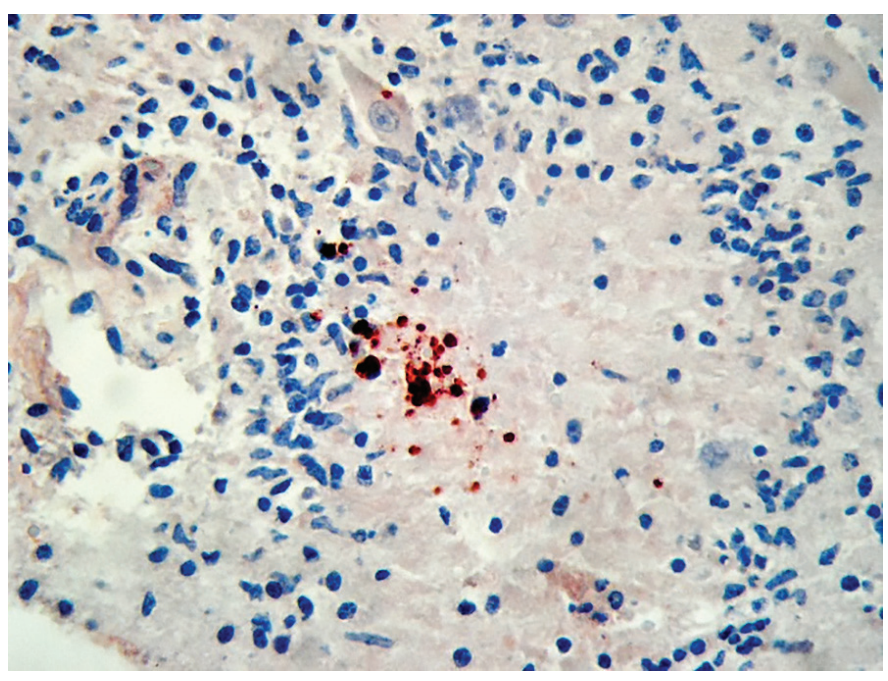

Fig.3. Positive immunostaining to Neospora caninum tachyzoites in central nervous system of bovine fetus. Mayer haematoxylin, obj. $40 \mathrm{x}$

$\begin{array}{llllllllllll}1 & 2 & 3 & 4 & 5 & 6 & 7 & 8 & 9 & 10 & 11 & 12\end{array}$

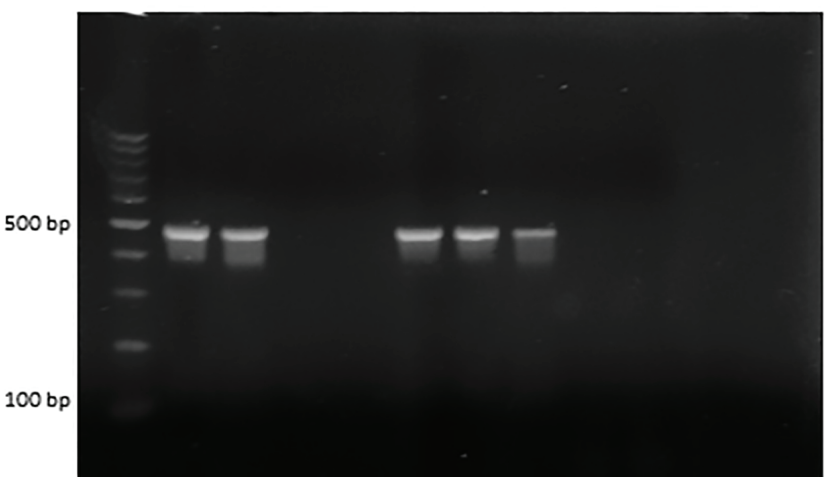

Fig.4. Brucella abortus PCR, products obtained using primers pairs IS 711/All Bru (498 pb). Vertical lanes = size marker, $100 \mathrm{pb}(1)$, positive control (2), B. abortus positives fetuses $(3,6,7,8)$, $B$. abortus negatives fetuses $(4,5)$, negative control $(10)$, without samples $(11,12)$.

vaccination, serology test and slaughter policy, brucellosis is still present in Argentina. B. abortus was identified in six fetuses by culture isolation and in four fetuses by PCR. In the last case, the fetuses had been negative by culture, but the presence of microscopic lesions (neutrophilic bronchopneumonia and/or lymphohistiocytic meningitis or pericarditis) and PCR, confirmed the etiologic diagnosis.

Coincidently with Campero et al. (2003) C. fetus spp. was the second cause of abortion. Bovine campylobacteriosis is a venereal disease caused by $C$. fetus venerealis, while $C$. fetus fetus, an habitant of the intestine, cause sporadic abortions (Campero et al. 2017).Special culture and DFAT are routine diagnostic techniques for the disease, but don't allow to differentiate Campylobacter species (Schulze et al. 2006). The inclusion of PCR identified $C$. fetus venerealis species 
as the cause of abortion in 14 fetuses with diagnosis of campylobacteriosis.

L. pomona is the most important serovar associated with abortion storms in cattle (Campero et al. 2017). Despite this, leptospirosis is probably under-diagnosed. The culture is not practical because is costly and time-consuming. Silver stained histologic sections and DFAT are frequently used, but their sensibilities are low and experienced personnel are required (Anderson 2007, Holler 2012, Borel et al. 2014). Nevertheless, 11 cases of leptospirosis were diagnosis by DFAT and subsequently confirmed by PCR. The high incidence of the disease (Table 2) was probably related to the favorable climatic conditions registered during the period of this study.

Oportunistic bacteria (Escherichia coli, Pasteurella spp., Salmonella spp., Staphylococcus spp., Streptococcus spp., Listeria spp., etc) and mycotic abortions cause sporadic bovine abortion at any stage of gestation, but more frequently during the last trimester (Campero et al. 2003, Anderson 2007, Borel et al. 2014). These microorganism are commonly found on mucosal surfaces of the host or its environments (poorly fermented silages, moldy stored or processed feedstuffs), but in some circumstances they can produce septicemia into the dam causing abortion. Opportunistic bacteria were isolated in pure culture from fetuses with consistent microscopic lesions due to Trueperella pyogenes and Listeria monocytogenes in the lung (neutrophilic bronchopneumonia) and liver (neutrophilic multifocal hepatitis), respectively. In addition, T. pyogenes was confirmed by the presence of intra-alveolar clusters of bacteria gram negative stained.

Aspergillus fumigatus, Candida spp., Absidia spp. and Mucorspp. are the main fungi implicated in sporadic bovine abortion. The former, was isolated in one fetus from abomasal content and lung. Circumscribed plaques on the skin, the presence of microscopic lesions (lymphohistiocitic bronchopneumonia, necrotic placentitis), and hiphas Grocott positive, confirmed the mycotic abortion in this study.

$N$. caninum was the most common infectious agent identified (Table 2). This result is not surprising, and consistent with previous reports of Argentina that shows the association between the high seroprevalence to $N$. caninum and the presence of abortions in beef and dairy cattle herds (Moore et al. 2002, Fernández et al. 2007, Morrell 2010). The IHC confirm the diagnosis of $N$. caninum as the cause of abortion when characteristic microscopic lesions and detectable antigens are both present in tissues, and no other infectious causes are identified (Anderson 2007, Borel et al. 2014). In this study, positive immunostaining to $N$. caninum tachyzoites was detected in the brain of 11 fetuses with focal lymphohistiocytic encephalitis with necrosis and/or gliosis. In addition, some fetuses had compatible inflammatory lesions in other organs. Only two of these 11 fetuses had antibodies to $N$. caninum; however, positive serology means the fetus mounted an immune response to the microorganism, but not proved that this microorganism caused the abortion (Anderson 2007, Campero et al. 2017). In addition, fetal serology depends on fetal age (fetal immunocompetence), duration of infection, and autolysis (Moore et al. 2003, Anderson 2007, Holler 2012).

PCR of N. caninum is more sensitive than histology and IHC (Baszler et al. 1999). However, PCR positive to N. caninum without fetal lesions is indicative of infection, but cannot explain the etiology of abortion. Eleven fetuses were N. caninum PCR positive, and six of them had positive serology. No multifocal necrosis and/or gliosis were present in the brain of any of these specimens, but moderate mononuclear cell infiltrates compatible to $N$. caninum infection were present in the meninges and/or myocardium, pericardium, lung and liver.

T. foetus usually produces early embryonic losses; however, occasional late term abortion can be produced by this parasite (Bon Durant 2007). Surprisingly, this agent was identified in one fetus of seven month from a beef herd. Campero et al. (2003) associate the poor diagnosis of trichomonosis from fetuses from beef herds of Argentina, to the difficulty of recover the specimens during the first trimester of gestation in those extensive production systems. The identification of trichomonads from abomasal fetal content by dark field microscopy and culture, and the lymphohistiocytic bronchopneumonia with occasional presence of multinucleated giant cells confirmed the diagnosis of abortion.

In Argentina BVDV and BHV are endemic diseases (Odeón et al. 2001).Virus isolation is the goal standard method and has the advantage that the isolate can be used for regional vaccine production; however, is a time consuming procedure and sometimes the sensitivity of viral isolation is reduced due to autolysis (Anderson 2007, Holler 2012). A proof of that was the absence of BHV isolation in all fetuses analyzed in this study. The PCR is a sensitive method for identifying BHV; mainly in the liver. (Takiuchi et al. 2005, Holler 2012). Three of 14 fetuses with serology to BHV were PCR positive from spleen. In addition, these fetuses had multifocal foci of hepatic necrosis compatible to herpesvirus.

Fetal infection by BVDV has variable outcomes depending on the moment of the infection, the biotype involved and others factors (Anderson 2007, Campero et al. 2017). Infertility, embryonic death, fetal resorption, mummification, malformations, abortion and birth of persistently infected lives calves had been associated to this virus. We isolated BVDV in two fetuses from beef and dairy herds, respectively. Both fetuses had characteristic microscopic lesions in the heart and other tissues, without vasculitis, but fetal lesions by this virus are quite variable (Anderson 2007).

None of 15 fetuses with serology to BVDV were PCR positive; being absent the microscopic lesions in those fetuses. This result indicates fetal viral infection, but excludes BVDV as the cause of abortion.

\section{CONCLUSIONS}

Bacterial and viral isolation are the "gold standard" test for the diagnosis of bovine abortion, however one of their main limitation is the low sensibility. Direct antigen and/or DNA detection are the currently preferred methods used for this purpose. Regardless of the techniques used, in all cases, the results must to be confirmed by the presence of compatible microscopic lesions. Failure of these conditions indicates fetal infection, but do not prove the cause of the abortion.

In this study, the fetuses diagnosed by PCR alone, or PCR combined to others test (fetal serology or DFAT), had histopathological lesions corresponding to the agent involved.

The criteria employed in the present study should be considered for future investigations of bovine abortion in order to avoid false-positive results.

Acknowledgements.- FONCyT 08-1139 supported this research. We thank Dr. Francisco Uzal for the revision of the manuscript, Drs. Maia Marin and Erika Gonzalez Altamiranda for excellent technical assistance with the PCR of BHV and BVDV.

Conflict of interest statement.- The authors have no competing interest. 


\section{REFERENCES}

Anderson M.L. 2007. Infectious causes of bovine abortion during mid- to lategestation. Theriogenology 68(3):474-486. <http://dx.doi.org/10.1016/j. theriogenology.2007.04.001><PMid:17467787>

Anderson M.L., Blanchard P.C., Barr B.C. \& Hoffman R.L. 1990. A survey of causes of bovine abortion occurring in the San Joaquin Valley, California. J. Vet. Diagn. Invest. 2(4):283-287. <http://dx.doi.org/10.1177/104063879000200405> $<$ PMid:2095280>

Anderson M.L., Blanchard P.C., Barr B.C., Dubey J.P., Hoffman R.L. \& Conrad P.A. 1991. Neospora-like protozoan infection as a major cause of abortion in California dairy cattle. J. Am. Vet. Med. Assoc. 198(2):241-244. <PMid:2004983>

Baszler T.V., Gay L.J., Long M.T. \& Mathison B.A. 1999. Detection by PCR of Neospora caninum in fetal tissues from spontaneous bovine abortion. J. Clin. Microbiol. 37(12):4059-4064. <PMid:10565932>

Bon Durant R.H. 2007. Selected diseases and conditions associated with bovine conceptus loss in the first trimester. Theriogenology 68(3):461-473. <http:// dx.doi.org/10.1016/j.theriogenology.2007.04.022> <PMid:17548105>

Bon Durant R.H., Campero C.M., Anderson M.L. \& Van Hoosear K.A. 2003. Detection of Tritrichomonas foetus by polymerase chain reaction in cultured isolated, cervicovaginal mucus, and formalin-fixed tissues from infected heifers and fetuses. J. Vet. Diagn. Invest. 15(6):579-584. <http://dx.doi. org/10.1177/104063870301500613><PMid:14667024>

Borel N., Frey C.F., Gottstein B., Hilbe M., Pospischil A., Franzoso F.D. \& Waldvogel A. 2014. Laboratory diagnosis of ruminant abortion in Europe. Vet. J. 200(2):218-229. <http://dx.doi.org/10.1016/j.tvjl.2014.03.015> $<$ PMid:24709519>

Campero C.M. 2006. Causas infecciosas y parasitarias del aborto bovino. Mundo Ganadero 17:31-35.

Campero C.M., Cantón G.J. \& Moore P.D. 2017. Introducción y patogénesis de las pérdidas reproductivas en bovinos, p.29-47. In: Campero C.M., Cantón G.J. \& Moore D.P. (Eds), Abortos y Otras Pérdidas Reproductivas en Bovinos: diagnóstico y control. Hemisferio Sur, Buenos Aires, Argentina.

Campero C.M., Catena M. \& Medina D. 1986. Caldo infusión hígado para el cultivo de Tritrichomonas foetus. Vet. Argentina 3:80-81.

Campero C.M., Moore D.P., Odeón A.C., Cipolla A.L. \& Odriozola E. 2003. Aetiology of bovine abortion in Argentina. Vet. Res. Commun. 27(5):359369. <http://dx.doi.org/10.1023/A:1024754003432><PMid:14509450>

Corbellini L.G., Pescador C.A., Frantz F., Wunder E., Steffen D., Smith D.R. \& Driemeier D. 2006. Diagnostic survey of bovine abortion with special reference to Neospora caninum infection: Importance, repeated abortion and concurrent infection in aborted fetuses in Southern Brazil. Vet. J. 172(1):114120. <http://dx.doi.org/10.1016/j.tvjl.2005.03.006><PMid:16772136>

Cortez A., Castro A.M.G., Heinemann M.B., Soares R.M., Leite R.C., Scarcelli E., Genovez M.E., Alfieri A.A. \& Richtzenhain L.J. 2006. Detection of Brucella spp., Leptospira spp., bovine herpesvirus and bovine viral diarrhea virus nucleic acids in aborted fetuses and bovines dead perinatal. Arq. Bras. Med. Vet. Zootec. 58(6):1226-1228. <http://dx.doi.org/10.1590/S010209352006000600036>

Dubey J.P., Carpenter J.L., Speer C.A., Topper M.J. \& Uggla A. 1988. Newly recognized fatal protozoan disease of dogs. J. Am. Vet. Med. Assoc. 192(9):1269-1263. <PMid:3391851>

Fernández M.E., Campero C.M., Morrell E., Cantón G.J., Moore D.P., Cano A., Malena R., Odeón A.C., Paolicchi F. \& Odriozola E.R. 2007. Pérdidas reproductivas en bovinos causadas por abortos, muertes prematuras, natimortos y neonatos: casuística del período 2006-2007. Revta Med. Vet. 88:246-254.
Holler L.D. 2012. Ruminant abortion diagnostics. Vet. Clin. N. Am., Food Anim. Pract. 28(3):407-418. <http://dx.doi.org/10.1016/j.cvfa.2012.07.007> <PMid:23101668>

Hubbert W.T., Booth G.D., Bolton W.D., Dunne H.W., McEntee K., Smith R.E. \& Tourtellotte M.E. 1973. Bovine abortions in five Notheasterns states, 19601970: evaluation of diagnostic laboratory data. Cornell Vet. 63(2):291-316. <PMid:4703675>

Jamaluddin A.A., Case J.T., Hird D.W., Blanchard P.C., Peauroi J.R. \& Anderson M.L. 1996. Dairy cattle abortion in California: evaluation of diagnostic laboratory data. J. Vet. Diagn. Invest. 8(2):210-218. <https://doi. org/10.1177/104063879600800211 ><PMid: 8744743>

Kirkbride C.A. 1986. Examination of bovine and ovine fetuses. Vet. Clin. N. Am., Food Anim. Pract. 2(1):61-83. <http://dx.doi.org/10.1016/S07490720(15)31281-0><PMid:3485006>

Kirkbride C.A. 1990. Causes and prevention of bovine abortion. Bov. Proc. 23:75-80.

Kirkbride C.A. 1993. Bacterial agents detected in a 10-year study of bovine abortions and stillbirths. J. Vet. Diagn. Invest. 5(1):64-68. <http://dx.doi. org/10.1177/104063879300500114 > <Mid:8466983>

Mérien F., Amouriaux P., Perolat P., Baranton G. \& Saint Girons I. 1992. Polymerase chain reaction for detection of Leptospira spp. in clinical samples. J. Clin. Microbiol. 30(9):2219-2224. <PMid:1400983>

Moore D.P., Campero C.M., Odeón A.C., Bardón J.C., Silva-Paulo P., Paolicchi F.A. \& Cipolla A.L. 2003. Humoral immune response to infectious agents in aborted bovine fetuses in Argentina. Revta Arg. Microbiol. 35(3):143148. <PMid:14587376>

Moore D.P., Campero C.M., Odeón A.C., Posso M.A., Cano D., Leunda M.R., Basso W., Venturini M.C. \& Späth E. 2002. Seroepidemiology of beef and dairy herds and fetal study of Neospora caninum in Argentina. Vet. Parasitol. 107(4):303-316. <http://dx.doi.org/10.1016/S0304-4017(02)00129-2> $<$ PMid:12163242>

Morrell E.L. 2010. Diagnostic characterization of infectious causes of bovine abortion. Doctoral Thesis, University of La Plata (UNLP), Argentina.

Odeón A.C., Späth E.J.A., Paloma E.J., Leunda M.R., Fernández-Sainz I.J., Pérez S.E., Kaiser G.G., Draghi M.G., Cetra B.M. \& Cano A. 2001. Prevalencia de anticuerpos al virus de la diarrea viral bovina, herpersvirus bovino y virus sincicial respiratorio bovino en Argentina. Revta Med. Vet. 82:216-220.

Richtzenhain L.J., Cortez A., Heinemann M.B., Soares R.M., Sakamoto S.M., Vasconcellos S.A., Higa Z.M., Scarcelli E. \& Genovez M.E. 2002. A multiplex PCR for the detection of Brucella spp. and Leptospira spp. DNA from aborted bovine fetuses. Vet. Microbiol. 87(2):139-147. <http://dx.doi.org/10.1016/ S0378-1135(02)00049-4><PMid:12034542>

Ridpath J.F., Bolin S.R. \& Dubovi E.J. 1994. Segregation of bovine viral diarrhea virus into genotypes. Virology 205(1):66-74. <http://dx.doi.org/10.1006/ viro.1994.1620><PMid:7975238>

SAS 2002. Guide for Personal Computer. 6th ed. SAS Institute, Cary, NC, USA.

Schulze F., Bagon A., Müller W. \& Hotzel H. 2006. Identification of Campylobacter fetus subspecies by phenotypic differentiation and PCR. J. Clin. Microbiol. 44(6):2019-2024.<http://dx.doi.org/10.1128/JCM.0256605> < PMid:16757592>

Seleem M.N., Boyle S.M. \& Sriranganathan N. 2010. Brucellosis: a re-emerging zoonosis. Vet. Microbiol. 140(3/4):392-398. <http://dx.doi.org/10.1016/j. vetmic.2009.06.021><PMid:19604656>

Silva T.M.A., Oliveira R.G., Mol J.P.S., Xavier M.N., Paixão T.A., Cortez A., Heinemann M.B., Richtzenhain L.J., Lage A.P. \& Santos R.L. 2009. Diagnóstico etiológico del aborto infeccioso bovino por PCR. Ciência Rural 39(9):2563-2570. <http://dx.doi.org/10.1590/S0103-84782009000900028> 
Smith C.R., Ketterer P.J., McGowan M.R. \& Corney B.G. 1994. A review of laboratory techniques and their use in the diagnosis of Leptospira interrogans serovar hardjo infection in cattle. Aust. Vet. J. 71(9):290-294. <http:// dx.doi.org/10.1111/j.1751-0813.1994.tb03447.x><PMid:7818437>

Takiuchi E., Medici K.C., Alfieri A.F. \& Alfieri A.A. 2005. Bovine herpesvirus type 1 abortions detected by semi-nested PCR in Brazilian cattle herds. Res. Vet. Sci. 79(1):85-88. <http://dx.doi.org/10.1016/j.rvsc.2004.11.005> <PMid:15894030>

Thurmond M.C., Blanchard P.C. \& Anderson M.L. 1994. An example of selection bias in submissions of aborted bovine fetuses to a diagnostic laboratory. J. Vet. Diagn. Invest. 6(2):269-271. <http://dx.doi. org/10.1177/104063879400600224><PMid:8068765>

Tramuta C., Lacerenza D., Zoppi S., Goria M., Dondo A., Ferroglio E., Nebbia P. \& Rosati S. 2011. Development of a set of multiplex standard polymerase chain reaction assays for the identification of infectious agents from aborted bovine clinical samples. J. Vet. Diagn. Invest. 23(4):657-664. <http://dx.doi. org/10.1177/1040638711407880><PMid:21908306>
Van Maanen C., Wouda W., Schares G., Von Blumroder D., Conraths F.J., Norton R., Williams D.J., Esteban-Redondo I., Innes E.A., Mattsson J.G., Bjorkman C., Fernández-García A., Ortega-Mora L.M., Muller N., Sager H. \& Hemphill A. 2004. An interlaboratory comparison of immunohistochemistry and PCR methods for detection of Neospora caninum in bovine foetal tissues. Vet. Parasitol. 126(4):351-364. <http://dx.doi.org/10.1016/j. vetpar.2004.08.016 ><PMid:15567040>

Wouda W., Moen A.R., Visser I.J. \& van Knapen F. 1997. Bovine fetal neosporosis a comparison of epizootic and sporadic abortion cases and different age classes with regard to lesion severity and immunohistochemical identification of organisms in brain, heart, and liver. J. Vet. Diagn. Invest. 9(2):180-185. <http://dx.doi.org/10.1177/104063879700900212><PMid:9211238>

Yaeger M.J. \& Holler L.D. 2007. Bacterial causes of bovine infertility and abortion, p.389-398. In: Youngquist R.S. \& Threlfall W.R. (Eds), Current Therapy in Large Animal Theriogenology. 2nd ed. W.B. Saunders, Philadelphia. <http://dx.doi.org/10.1016/B978-072169323-1.50052-0> 